\title{
Survivin gene levels in the peripheral blood of patients with gastric
} cancer independently predict survival

\author{
Loris Bertazza $^{1,2}$, Simone Mocellin*1, Alberto Marchet ${ }^{1}$, Pierluigi Pilati ${ }^{1}$, \\ Joseph Gabrieli ${ }^{1}$, Romano Scalerta ${ }^{1}$ and Donato Nitti ${ }^{1}$
}

Address: ${ }^{1}$ Department of Oncological \& Surgical Sciences, Section of Clinica Chirurgica 2, University of Padova, via Giustiniani 2, 35128, Padua, Italy and 2Istituto Oncologico Veneto IRCCS, via Gattamelata 64, 35128, Padua, Italy

Email: Loris Bertazza - loris.bertazza@unipd.it; Simone Mocellin* - simone.mocellin@unipd.it; Alberto Marchet - marchet@unipd.it; Pierluigi Pilati - pl.pilati@unipd.it; Joseph Gabrieli - josephgabrieli@yahoo.it; Romano Scalerta - romano.scalerta@unipd.it;

Donato Nitti - donato.nitti@unipd.it

* Corresponding author

Published: 22 December 2009

Journal of Translational Medicine 2009, 7:III doi:I0.1 186/1479-5876-7-II I
Received: 24 August 2009

Accepted: 22 December 2009

This article is available from: http://www.translational-medicine.com/content/7/I/I I I

(C) 2009 Bertazza et al; licensee BioMed Central Ltd.

This is an Open Access article distributed under the terms of the Creative Commons Attribution License (http://creativecommons.org/licenses/by/2.0), which permits unrestricted use, distribution, and reproduction in any medium, provided the original work is properly cited.

\begin{abstract}
Background: The detection of circulating tumor cells (CTC) is considered a promising tool for improving risk stratification in patients with solid tumors. We investigated on whether the expression of CTC related genes adds any prognostic power to the TNM staging system in patients with gastric carcinoma.
\end{abstract}

Methods: Seventy patients with TNM stage I to IV gastric carcinoma were retrospectively enrolled. Peripheral blood samples were tested by means of quantitative real time PCR (qrtPCR) for the expression of four CTC related genes: carcinoembryonic antigen (CEA), cytokeratin-19 (CK 19), vascular endothelial growth factor (VEGF) and Survivin (BIRC5).

Results: Gene expression of Survivin, CK 19, CEA and VEGF was higher than in normal controls in $98.6 \%, 97.1 \%, 42.9 \%$ and $38.6 \%$ of cases, respectively, suggesting a potential diagnostic value of both Survivin and CK19. At multivariable survival analysis, TNM staging and Survivin mRNA levels were retained as independent prognostic factors, demonstrating that Survivin expression in the peripheral blood adds prognostic information to the TNM system. In contrast with previously published data, the transcript abundance of CEA, CK 19 and VEGF was not associated with patients' clinical outcome.

Conclusions: Gene expression levels of Survivin add significant prognostic value to the current TNM staging system. The validation of these findings in larger prospective and multicentric series might lead to the implementation of this biomarker in the routine clinical setting in order to optimize risk stratification and ultimately personalize the therapeutic management of these patients.

\section{Background}

Gastric cancer represents the fourth most common cancer and second leading cause of cancer-related death world- wide. The estimated current incidence of gastric cancer is approximately 16.2/100 000 persons/year (world standardized rate, WSR), with highest incidences in Eastern 
Asia, Eastern Europe and South America [1]. At present the only prognostic system routinely employed for the management of gastric cancer patients is based on the International Union Against Cancer Tumor-Node-Metastasis (TNM) staging system [2], in which the degree of tumor penetration $(\mathrm{pT})$ and nodal status $(\mathrm{pN})[3]$ are the two main prognostic indicators in patients without distant metastatic disease. Patients in early stages are considered candidates for cure by surgery. However, $50 \%$ of gastric cancer patients suffer from tumor relapses even after radical surgery $[4,5]$. Thus, the current staging system does not seem to accurately predict individual patient risk of cancer recurrence. Indeed this classification identifies broad categories with significantly different prognostic subgroup within each stage, which make this system suboptimal for a personalized therapeutic approach. This is exemplified by the fact that some patients currently classified as "low-risk" are not submitted to adjuvant therapy, although they do experience disease relapse. Vice versa, some patients currently undergoing adjuvant therapy because of "high risk" TNM classification, would not need this treatment [6]. In order to address this issue and improve upon the prognosis of patients, new parameters reliably predicting patients' outcome are urgently needed. Patients who had undergone potentially curative surgeries retain the risk of recurrence that originates from microscopic tumor residues known as minimal residual disease (MRD). MRD can affect different body compartments, including the bone marrow, lymph nodes and peripheral blood [7]. In recent years, several studies have focused on the detection of circulating tumor cells (CTC) with respect to their clinical implications for patients with gastric cancer. As a result, quantitative real time polymerase chain reaction (qrtPCR) and variations of this technique, which is considered to be the most sensitive method for evaluating gene expression, have been used in the detection of tumor markers that indicate the presence of CTC in the blood [8].

In the current analysis, we aimed to profiling the peripheral blood of 70 patents affected with gastric adenocarcinoma by using qrtPCR. We tested four biomarkers, two of the presence, ad two of the aggressiveness of the tumor, and one of these, the Survivin, add independent prognostic power to the TMN staging system. This might allow for a better stratification of patient's risk and thus a better therapeutic management, especially in the adjuvant setting.

\section{Methods \\ Patients}

In this study we enrolled 70 patients ( 39 men, 31 women; age range 28 - 90 years, median age 68 years) who underwent surgery (total or partial gastrectomy) for histologically proven gastric carcinoma between October 1998 and
November 2007, and for whom a peripheral blood sample was available. The study, which is in compliance with the Helsinki Declaration, was approved by the Local Ethical Committee of the University of Padova (approval number: 70/2006). Written informed consent regarding the use of biological specimens for investigational purposes was obtained from all patients. At the time of the analysis, 33 (47.1\%) were alive whereas 37 (52.9\%) had died. Median follow-up was 15 months (range: 6-119 months). Median survival was 25 months. Tumor characteristics are summarized in Table 1 . The depth of tumor invasion (T category), extent of lymph node metastasis ( $\mathrm{N}$ category) and macroscopic metastasis ( $\mathrm{M}$ category) were categorized according to the UICC TNM staging system.

\section{Cell lines}

The human gastric carcinoma cell line NCI-N87, obtained from the American Type Culture Collection (Manassas, USA), was incubated in RPMI-1640 medium (Invitrogen Gibco, Carlsbad, CA, USA) containing 10\% fetal calf serum (Euroclone - Celbio, Pero, MI), $10 \mathrm{mM}$ Hepes, 1 $\mathrm{mM}$ Sodium Pyruvate (Sigma-Aldrich, St. Louis, MO), at $37^{\circ} \mathrm{C}$ in $5 \% \mathrm{CO}_{2}$.

NCI-N87 is a gastric carcinoma cell line derived from a liver metastasis of a well differentiated carcinoma of the stomach taken prior to cytotoxic therapy. According to the manufacturer's datasheet, cells express the surface glycoproteins carcinoembryonic antigen (CEA).

Table I: Patients and tumor characteristics.

\begin{tabular}{llcc}
\hline & Parameters & N & (\%) \\
\hline Patients & all & 70 & $(100.0)$ \\
& male & 39 & $(55.7)$ \\
& female & 31 & $(44.3)$ \\
\hline \multirow{2}{*}{ Age (years) } & & & \\
& $\leq 65$ & 21 & $(30.0)$ \\
& $>65$ & 49 & $(70.0)$ \\
\hline \multirow{2}{*}{ Location } & & & \\
& multicentric & 5 & $(7.1)$ \\
& upper third & 11 & $(15.7)$ \\
& middle third & 19 & $(27.1)$ \\
& lower third & 35 & $(50.0)$ \\
\hline \multirow{2}{*}{ TNM stage } & & & \\
& I (IA + IB) & 10 & $(14.3)$ \\
& II & 14 & $(20.0)$ \\
& III (IIIA + IIIB) & 19 & $(27.1)$ \\
& IV & 27 & $(38.6)$ \\
\hline
\end{tabular}




\section{Cell spiking experiments}

A cell spiking study was performed in order to determine the sensitivity of this qrtPCR technique for detecting cancer cells in peripheral blood mononuclear cells (PBMC). The PBMC were obtained from healthy volunteers, and were counted and diluted 1:1 in RPMI medium. Gastric cancer cells N87 were counted and serially diluted from 1 $\times 10^{6}$ cells $/$ milliliter to $1 \mathrm{cell} / \mathrm{milliliter}$ in the PBMC. Total RNA was extracted and reverse- transcribed from 2 milliliters of each fraction. qrtPCR for two genes of interest were then performed, as described below.

\section{Sample collection, RNA extraction and cDNA synthesis}

A $6 \mathrm{ml}$ aliquot of venous blood was obtained from each patient at the time of surgery. Sample processing was performed within two hours after blood withdrawal. Sample was centrifuged at $2000 \times \mathrm{g}$ for 10 minutes, and the PBMC fraction was collected and stored in liquid nitrogen.

Frozen samples were thawed and total RNA was extracted using the Guanidinium Thiocyanate-Phenol-Chloroform method (Trizol Reagent, Invitrogen, Carlsbad, CA, US). The integrity of the isolated RNA was established by qrtPCR analysis of the endogenous reference gene beta actin (b-actin) as described below [9].

Total RNA ( $7 \mu$ g per $100 \mu$ f final reaction volume) was reverse-transcribed using random primers and MultiScribe Reverse Transcriptase (High-Capacity cDNA reverse transcription kit, Applied Biosystems, Foster City, CA, USA). The reaction mixture was incubated for 10 minutes at $25^{\circ} \mathrm{C}$, then at $37^{\circ} \mathrm{C}$ for 120 minutes. cDNA was stored at $-80^{\circ} \mathrm{C}$ until use.

\section{Real-time quantitative polymerase chain reaction}

The transcriptional levels of four genes (i.e., carcinoembryonic antigen [CEA], cytokeratin-19 [CK19], Survivin and vascular endothelial growth factor [VEGF]) were measured in the peripheral blood of patients by means of quantitative real time PCR (qrtPCR) using the relative quantification method ( $2^{-\Delta \Delta \mathrm{Ct}}$ method) $[10,11]$. Using the $2^{-\Delta \Delta \mathrm{Ct}}$ method the data are presented as the fold-change in gene expression normalized by a reference gene and relative to a calibrator sample. The purpose of the normalization process is to adjust the value representing the transcriptional levels of each gene by the amount of mRNA present in each sample: this is usually obtained by dividing the expression levels of each gene of interest by those of a reference gene (also called "housekeeping" gene). Housekeeping genes are expressed constitutively and - ideally - are not affected by experimental manipulations: therefore, they should approximately reflect the total amount of mRNA tested in each sample [12]. As the reference gene in this study we used beta-actin, one of the most commonly used housekeeping genes.
In a relative quantification PCR study, the so called "calibrator" is represented by the gene expression of a chosen sample by which the expression profile of each sample of interest is adjusted: this approach enables the investigator to compare the expression profile of the samples of interest with each other in terms of their fold-change with respect to a single sample (the calibrator).

Usually, the calibrator is an untreated sample (e.g. in a functional study), a sample at time zero (e.g. in a timecourse study) or any unrelated sample (e.g. healthy controls in a patients study, or normal fibroblasts in a cancer cell line study) [10]. A pool of cDNA derived from PBMC of 20 healthy donors was used as the calibrator source in our study. Evaluation of the $2^{-\Delta \Delta \mathrm{Ct}}$ indicates the fold change in gene expression relative to the calibrator. For the calibrator the $\Delta \Delta \mathrm{Ct}$ equals zero, and $2^{0}$ equals one, so that the fold change in gene expression relative to the calibrator equals one, by definition.

The method was validated for our experimental system by verifying that the efficiencies of amplification of the targets and the b-actin genes were similar. TaqMan Gene Expression Assays specific for CEA, CK19, Survivin and VEGF were purchased from Applied Biosystems. To avoid amplifying contaminated genomic DNA, the primer pair was placed at the junction between two exons. The qrtPCR assay was performed using the ABI PRISM 7300 Sequence Detection system. The PCR reaction proceed in a mixture (30 $\mu \mathrm{l})$ containing $15 \mu \mathrm{l}$ of $2 \times$ TaqMan Universal PCR Master Mix, $1.5 \mu$ l of 20× TaqMan Gene Expression assay (all reagents from Applied Biosystems), $12.5 \mu \mathrm{l}$ of water and $1 \mu \mathrm{l}$ of cDNA template. Fifty cycles of amplification were performed at $95^{\circ} \mathrm{C}\left(15\right.$ seconds) and $60^{\circ} \mathrm{C}(1$ minute) and mRNA expression levels were normalized against quantified b-actin mRNA expression for each sample.

\section{Statistical analysis}

Statistical analyses were performed using the Stat View V. 4.57 software (Abacus Concepts, London, UK) and the StatXact V7.0.0 software (Cytel Software Corporation, USA). The correlation between gene levels (high versus low gene expression, as defined by the median value) and disease TNM staging categories was assessed by using the Cochrane-Armitage trend test. Survival curves were estimated using the Kaplan-Meyer method, and univariate survival comparisons were calculated according to the logrank test. The transcriptional levels of the four genes, along with anthropometric factors and TNM stages (according to the 5th edition of the AJCC TNM staging system released in 1997), were utilized as independent variables in the multivariate survival analysis, which was performed using the Cox proportional hazards regression model [13]. The selection of variables that significant con- 
tribute to the predictive model was performed by stepwise method. Probability values $<5 \%$ were considered statistically significant.

\section{Results}

\section{Cell spiking: sensitivity of qrtPCR technique}

In the N87 cell line, mRNA levels of the CEA, CK19, Survivin, and VEGF genes were highly expressed (Figure 1): therefore, this gastric carcinoma cell line represented a valid positive control for our experiments.

To establish the detection limit (sensitivity) of the qrtPCR technique, serial 10-fold dilutions (in PBMC) of N87 gastric carcinoma cells were assayed in triplicate by qrtPCR using CEA and Survivin as gene markers. CEA and Survivin mRNA were detected up to 1 cell/108 PBMC dilution: this corresponds to finding 1 to 10 malignant cells per $10 \mathrm{ml}$ of peripheral blood (data not shown).

\section{Expression markers in blood samples}

Peripheral blood samples from all 70 patients were evaluated for the four gene markers. The expression was positive (higher than calibrator) in $98.6 \%, 97.1 \%, 42.9 \%$, $38.6 \%$ of samples for Survivin, CK19, CEA, VEGF, respectively (Table 2). Since Survivin and CK19 gene levels found in nearly all patients are greater than those in

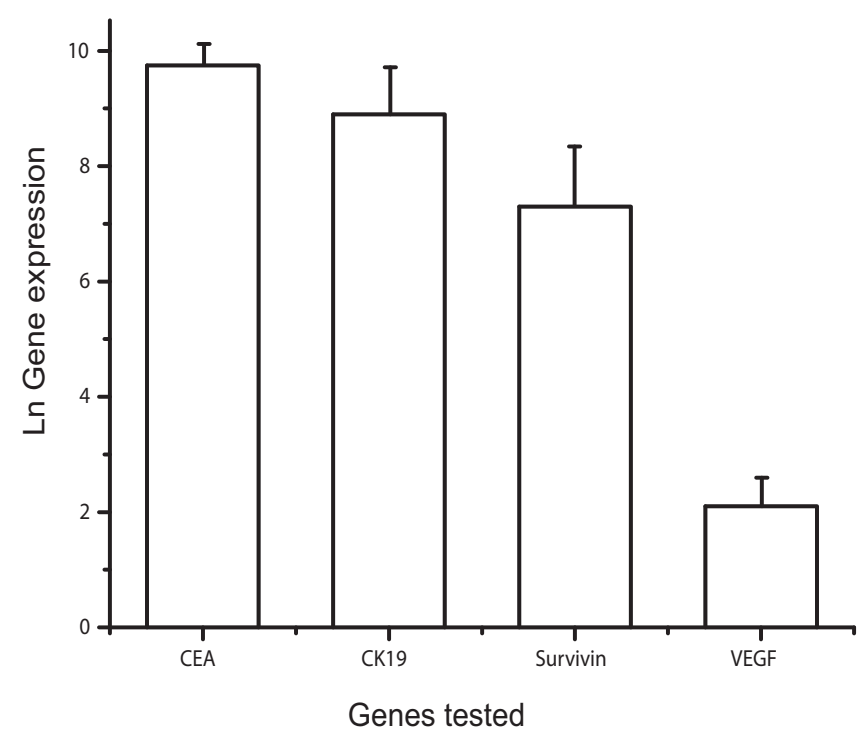

Figure I

Gene expression levels of the four genes of interest in N87 human gastric cancer cells (as measured by quantitative real time PCR: see text for details). The natural logarithm of the expression levels is reported on the $y$ axis: the axis origin $(0)$ represents the reference sample (called calibrator) with which all experimental samples are compared in the relative quantification method (see text for details). healthy controls, these findings point to a diagnostic potential of both genes.

Moreover, if we considered the 75th percentile of Survivin expression levels per stage, we had a significant increased trend $(\mathrm{p}=0.04)$ for stages from I to III, but not for stage IV (Figure 2).

\section{Survival analysis}

After a mean follow up of 26 months, the median overall survival (OS) for TNM stage I-II was not reached; the median OS for stage III and IV was 25 and 13 months, respectively (log-rank test $P$-value $<0.0001$, Figure 3 ).

Upon univariate survival analysis, among the four genes we have tested, only Survivin expression could identify two patient groups with significantly different prognosis. In fact, considering the 75th percentile of log-transformed gene transcription levels (1.508) as the cutoff point, median OS for high $(>1.508)$ and low $(\leq 1.508)$ Survivin mRNA abundance were 14 and 41 months, respectively $($ log-rank P-value $=0.036$, Figure 4$)$.

The multivariate survival analysis including TNM stage, age, gender and mRNA levels of the four markers showed that only TNM stage and Survivin mRNA levels measured in the peripheral blood independently predict patients' OS. The hazard ratio (HR) associated with Survivin levels indicates the increase in risk of death for 100 fold increase in Survivin expression (Table 3).

Since only these four independent variables were retained by the Cox model, this analysis suggests that Survivin gene expression can add useful prognostic information to well established factors such as the TNM staging system.

\section{Discussion}

In this study we found that transcriptional levels of Survivin measured in the peripheral blood of patients with gastric carcinoma independently correlate with their overall survival.

If validated in larger prospective studies, these results would allow to increase the prognostic power of conventional prognostic factors, which are currently embodied by the TNM staging parameters. This is of special relevance for patients with TNM stage I to III disease, for whom optimal risk stratification is essential to identify subjects with the highest likelihood to benefit from adjuvant treatments.

Our findings are of particular relevance also from the tumor biology viewpoint because the Survivin gene encodes a key anti-apoptotic protein belonging to the inhibitor of apoptosis protein (IAP) family. Beside being 
Table 2: Transcriptional levels of four prognostic markers in the peripheral blood of patients with gastric cancer.

\begin{tabular}{cccc}
\hline Marker & Above calibrator (\%)* & Below calibrator (\%)* & Undetectable (\%) \\
\hline Survivin & $69(98.6)$ & $1(1.4)$ & $0(0.0)$ \\
\hline CKI9 & $68(97.1)$ & $2(2.9)$ & $0(0.0)$ \\
\hline CEA & $30(42.9)$ & $21(30.0)$ & $19(27.1)$ \\
\hline VEGF & $27(38.6)$ & $43(61.4)$ & $0(0.0)$ \\
\hline
\end{tabular}

* Gene expression levels were measured by quantitative real time PCR: using the relative quantification method, samples were classified as above or below the levels found in the calibrator (pooled peripheral blood samples from healthy donors).

one of the best characterized anti-apoptotic factors [14], Survivin is the object of intense investigation due to the fact that in adults it is selectively expressed virtually only by cancers of different origin; moreover, its expression in the primary tumor has been associated with worse prognosis and resistance to conventional chemotherapeutics [15]. These observations make Survivin an ideal target for tumor-specific therapies, such as small molecule inhibitors and antigen-specific immunotherapy [16].

Survivin protein expression in primary tumors, including gastric cancer, has been investigated as a prognostic factor, higher levels being associated with worse cancer outcome [17]. About RNA expression, Survivin mRNA levels have been investigated as a marker of circulating tumor cells

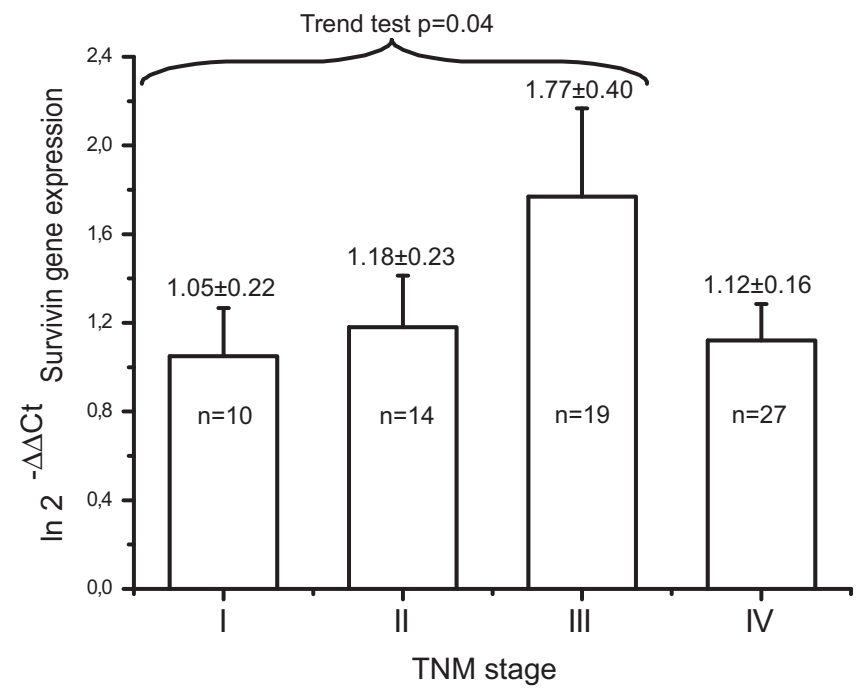

Figure 2

Survivin gene levels measured in the peripheral blood of $\mathbf{7 0}$ patients with TNM stage I to IV gastric cancer. The trend test analysis shows a significant increase in Survivin transcriptional levels across patients with stage I to III gastric cancer (trend test P-value $=0.04$ ). For each column is reported the mean \pm SD.
(CTC) in different kind of cancer, but the available data are scarce $[18,19]$. In a series of 26 gastric cancer patients, Survivin mRNA (as measured by means of ELISA-based qrtPCR) in the peripheral blood has been reported to correlate with patients' prognosis, the TNM staging being excluded from the final mutivariable model (forcing all variables into the Cox model) [20]. In our larger series (n $=70$ ), the prognostic role of Survivin blood levels is confirmed, although the TNM staging remains a significant prognostic factor in the final multivariable model (using the stepwise mode for variable selection). Despite the significant association with patients' prognosis, Survivin mRNA levels did not increase across all four TNM stages: the trend for increased transcriptional abundance was in fact demonstrated only in patients with stage I to III disease (Figure 2). This finding might depends upon the low sample sizes of the single TNM stages (and the consequent low statistical power) but might also indicates that Sur-

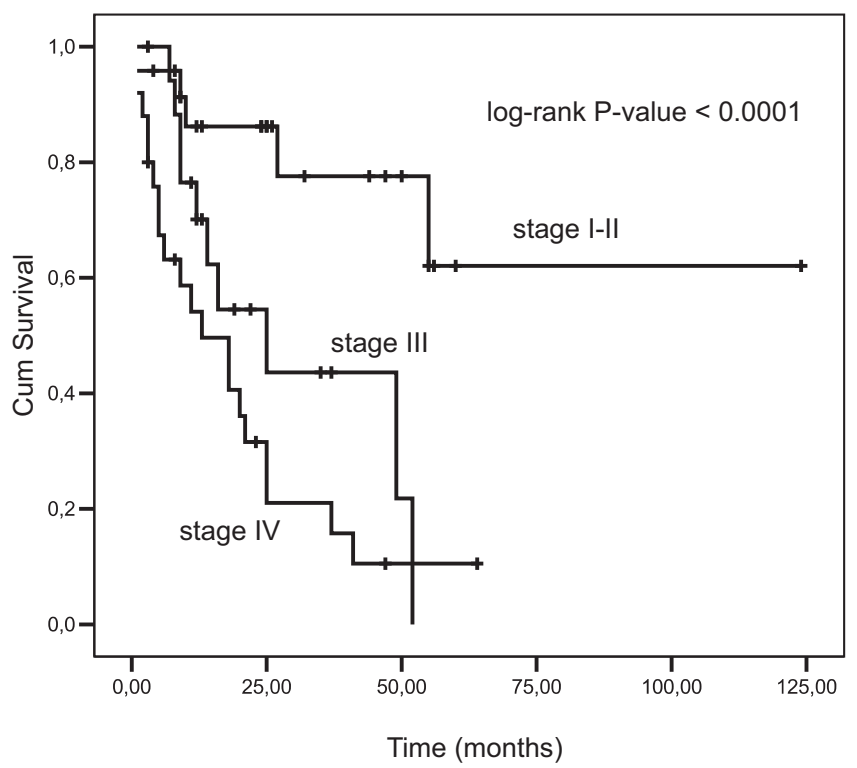

Figure 3

Overall survival for TNM stage I-II, III and IV for all patients (log-rank test $\mathrm{P}$-value $<\mathbf{0 . 0 0 0 I}$ ). 


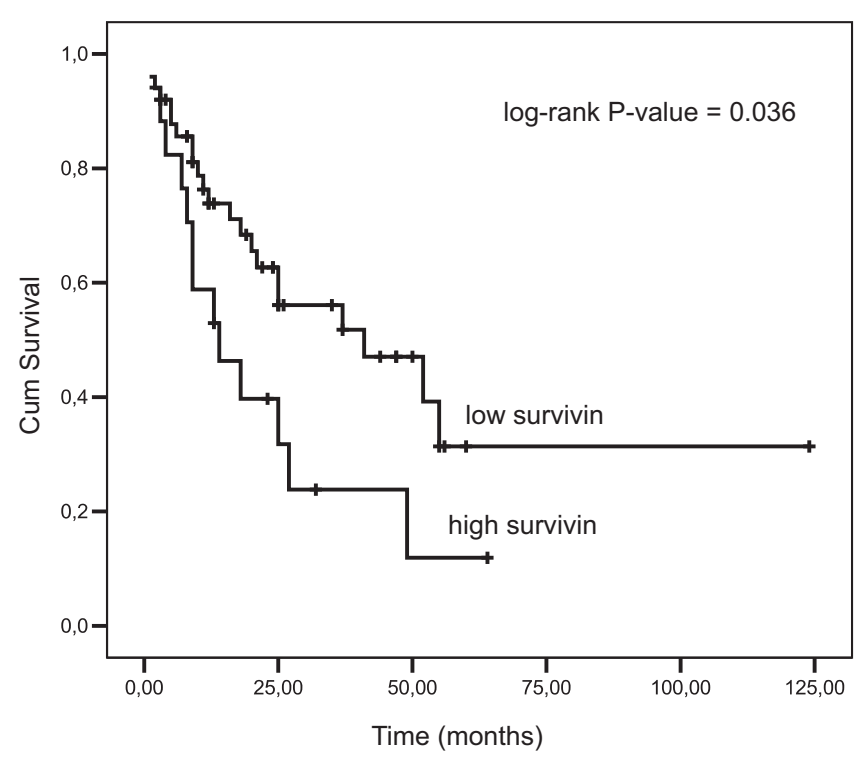

Figure 4

Kaplan-Meier survival curves of patients with high (> 75th percentile) or low (< 75th percentile) transcriptional levels of Survivin measured in the peripheral blood. Log-rank test P-value $=0.036$.

vivin plays a role in locoregional and not in distant metastatic disease (where other genes could be more relevant, as recently reported [21]).

Unlike other studies [9,22-26], the levels of CK19 and CEA did not correlate with patients survival in our series, either on univariable (data not shown) or multivariable survival analysis: this might depend upon several factors. First of all, the inclusion in our multivariable analysis (with a stepwise mode of variable selection) of a marker

Table 3: Multivariate survival analysis of 70 patients with gastric cancer.

\begin{tabular}{ccccc}
\hline Covariates & HR & \multicolumn{2}{c}{$95 \%$ Cl } & P-value \\
& & Lower limit & Upper limit & \\
\hline TNM stage I & I (reference) & - & - & - \\
\hline stage II & 1.20 & 1.01 & 1.45 & 0.048 \\
\hline stage III & 1.34 & 1.05 & 1.70 & 0.017 \\
\hline stage IV & 3.17 & 1.38 & 6.77 & 0.004 \\
\hline Survivin* & 1.34 & 1.14 & 1.53 & $<0.001$ \\
\hline
\end{tabular}

HR: hazard ratio; $\mathrm{Cl}$ : confidence interval; * the HR associated with Survivin levels indicates the increase of death risk for 100 -fold increase in Survivin expression. not considered by other Authors makes any comparison unfeasible.

Of note, some positive reports only use univariable survival analysis, which jeopardizes the reliability and reproducibility of their results, once adjustment for well established prognostic factors (i.e. TNM stages) were implemented $[9,25,27,28]$. Moreover, in line with our results other investigators do report lack of association between cytokeratins positive cells presence and prognosis [29] (Table 4).

These conflicting data might depend on the fact that CK19 and CEA are markers of CTC presence but not necessarily of CTC ability to metastasize: in fact, it is well accepted that only a subset of CTC has the biological potential of giving rise to metastatic deposits, while most CTC ultimately die without being harmful for the host [7]. Accordingly, markers of CTC "aggressiveness" such as Survivin might reveal to be more informative in terms of correlation with patients' prognosis.

Of note, in the present study the mRNA abundance of Survivin and CK19 was always greater than that found in healthy controls except for one and two cases, respectively. This underscores the importance of using a quantitative method (qrtPCR) that enabled us to stratify patients risk on a continuous scale, whereas standard PCR would have classified virtually all patients as positive. On the other side, this finding - which to the best of our knowledge has never been reported before - suggests that these genes might be exploited also for diagnostic purposes, although a dedicated study specifically designed for this aim is warranted.

As a final consideration, we would like to observe that PCR-based methods do not allow to identify the cell source of the measured markers: in fact, all these methods require the lysis of the cells harvested from the peripheral blood of patients in order to extract the mRNA used to assess the expression of target genes. Besides CTC, other potential sources of PCR-detected genes are PBMC, circulating endothelial cells (CEC), bone marrow derived circulating stem cells as well as skin cells (e.g. keratinocytes, fibroblasts, melanocytes) contaminating the sample during blood withdrawal. Nevertheless, CTC are likely to be the principal cell source for Survivin as its expression is very limited in normal adult tissues and is instead mainly restricted to malignant cells [30]. In this regard, cytometric methods are less prone to false positive results, as they imply antibody-based cell sorting followed by cytological identification of tumor cells that precedes their phenotypic characterization [31]. 
Table 4: Selected series analyzing the prognostic role of circulating tumor cells (CTC) in patients with gastric cancer.

\begin{tabular}{|c|c|c|c|c|c|c|c|}
\hline Author & Year & Ref. & Patients & Method & Survival analysis & Markers & Findings \\
\hline Koga T et. al. & 2008 & [9] & 101 & $\begin{array}{c}\text { Quantitative RT- } \\
\text { PCR }\end{array}$ & Univariate & $\begin{array}{l}\text { CK 18, CK } 19 \text {, } \\
\text { CK20, CEA }\end{array}$ & $\begin{array}{l}\text { CKI9 is the better } \\
\text { marker, and is usable } \\
\text { to estimate prognosis } \\
\text { or for adjuvant } \\
\text { treatment }\end{array}$ \\
\hline Yie SM et. al. & 2008 & {$[20]$} & 26 (gastric cancer) & RT-PCR ELISA & Multivariate & Survivin & $\begin{array}{l}\text { Status of Survivin- } \\
\text { expressing CTC is a } \\
\text { strong and } \\
\text { independent predictor } \\
\text { for recurrence }\end{array}$ \\
\hline Hiraiwa $\mathrm{K}$ et. al. & 2008 & {$[22]$} & 44 (gastric cancer) & CellSearch system & Multivariate & $\begin{array}{c}\text { CD45 (-) cells vs } \\
\text { CK (+) cells }\end{array}$ & $\begin{array}{c}\text { CTSs significantly } \\
\text { correlated with } \\
\text { advanced tumor stage }\end{array}$ \\
\hline Illert B et. al. & 2005 & {$[23]$} & 70 & $\begin{array}{c}\text { Quantitative RT- } \\
\text { PCR }\end{array}$ & Multivariate & CK20 & $\begin{array}{c}\text { CK20 is an } \\
\text { independent } \\
\text { prognostic marker }\end{array}$ \\
\hline Yeh $\mathrm{KH}$ et. al. & 1998 & {$[24]$} & 34 & $\begin{array}{c}\text { Nested quantitative } \\
\text { RT-PCR }\end{array}$ & Univariate & CKI9 & $\begin{array}{c}\text { CK } 19 \text { expressing CTC } \\
\text { are associated with } \\
\text { poor prognosis }\end{array}$ \\
\hline Seo JH et. al. & 2005 & {$[25]$} & 46 & $\begin{array}{c}\text { Quantitative RT- } \\
\text { PCR }\end{array}$ & Not performed & CEA & $\begin{array}{l}\text { CEA mRNA is } \\
\text { significantly correlated } \\
\text { with clinical } \\
\text { recurrence }\end{array}$ \\
\hline Wu CH et. al. & 2006 & {$[26]$} & 42 & $\begin{array}{c}\text { Quantitative RT- } \\
\text { PCR }\end{array}$ & Not performed & $\begin{array}{l}\text { hTERT, CK 19, } \\
\text { CK20, CEA }\end{array}$ & $\begin{array}{l}\text { CEA mRNA is } \\
\text { correlated with higher } \\
\text { risk of postoperative } \\
\text { recurrence/metastasis }\end{array}$ \\
\hline Uen $\mathrm{YH}$ et. al. & 2006 & {$[27]$} & 52 & $\begin{array}{c}\text { Quantitative RT- } \\
\text { PCR }\end{array}$ & Univariate & c-MET, MUCI & $\begin{array}{c}\text { c-Met and } \\
\text { MUCImRNA } \\
\text { significantly correlate } \\
\text { with prognosis }\end{array}$ \\
\hline Mimori $\mathrm{K}$ et. al. & 2008 & {$[28]$} & 810 & $\begin{array}{c}\text { Quantitative RT- } \\
\text { PCR }\end{array}$ & Univariate & MTI-MMP & $\begin{array}{l}\text { MTI-MMP is an } \\
\text { independent factor for } \\
\text { determining } \\
\text { recurrence and distant } \\
\text { metastasis }\end{array}$ \\
\hline $\begin{array}{l}\text { Pituch-Noworolska } \\
\text { A et. al. }\end{array}$ & 2007 & [29] & 57 & Flow cytometry & Univariate & $\begin{array}{c}\text { CD45 (-) cells vs } \\
\text { CK (+) cells }\end{array}$ & $\begin{array}{l}\text { The presence of CK } \\
(+) \text { cells is of no } \\
\text { prognostic value }\end{array}$ \\
\hline
\end{tabular}

\section{Conclusions}

Gene expression levels of Survivin add significant prognostic value to the current TNM staging system of patients with gastric carcinoma. The validation of these findings in larger prospective series might lead to optimize the risk stratification and ultimately to personalize the therapeutic management of these patients.

\section{Competing interests}

The authors declare that they have no competing interests.

\section{Authors' contributions}

LB conceived the study design, handled biological samples, performed qrtPCR analysis and drafted the manuscript. SM conceived the study design, performed statistical data analysis and drafted the manuscript. JG, AM and PP participated in the design of the study and col- 
lected the clinical data of patients. RS handled samples collection and storage until RNA extraction. DN coordinated the study and participated in manuscript writing and editing. All authors read and approved the final version of the manuscript.

\section{References}

I. de Vries AC, Meijer GA, Looman CW, Casparie MK, Hansen BE, van Grieken NC, Kuipers Ej: Epidemiological trends of pre-malignant gastric lesions: a long-term nationwide study in the Netherlands. Gut 2007, 56:1665-1670.

2. Greene FL, Sobin LH: The TNM system: our language for cancer care. I Surg Oncol 2002, 80: I 19-120.

3. Aurello P, D'Angelo F, Rossi S, Bellagamba R, Cicchini C, Nigri G, Ercolani G, De Angelis R, Ramacciato G: Classification of lymph node metastases from gastric cancer: comparison between $\mathbf{N}$-site and $\mathbf{N}$-number systems. Our experience and review of the literature. Am Surg 2007, 73:359-366.

4. Goldberg RM, Fleming TR, Tangen CM, Moertel CG, Macdonald JS, Haller DG, Laurie JA: Surgery for recurrent colon cancer: strategies for identifying resectable recurrence and success rates after resection. Eastern Cooperative Oncology Group, the North Central Cancer Treatment Group, and the Southwest Oncology Group. Ann Intern Med 1998, 129:27-35.

5. Marrelli D, De Stefano A, de Manzoni G, Morgagni P, Di Leo A, Roviello F: Prediction of recurrence after radical surgery for gastric cancer: a scoring system obtained from a prospective multicenter study. Ann Surg 2005, 24I:247-255.

6. Janunger KG, Hafstrom L, Glimelius $B$ : Chemotherapy in gastric cancer: a review and updated meta-analysis. Eur J Surg 2002, 168:597-608.

7. Bertazza L, Mocellin S, Nitti D: Circulating tumor cells in solid cancer: tumor marker of clinical relevance? Curr Oncol Rep 2008, I0:137-146.

8. Vogel I, Kalthoff $\mathrm{H}$ : Disseminated tumour cells. Their detection and significance for prognosis of gastrointestinal and pancreatic carcinomas. Virchows Arch 2001, 439:109-117.

9. Koga T, Tokunaga E, Sumiyoshi Y, Oki E, Oda S, Takahashi I, Kakeji Y, Baba $\mathrm{H}$, Maehara $Y$ : Detection of circulating gastric cancer cells in peripheral blood using real time quantitative RT-PCR. Hepatogastroenterology 2008, 55: I I3I-II35.

10. Livak KJ, Schmittgen TD: Analysis of relative gene expression data using real-time quantitative PCR and the 2(-Delta Delta C(T)) Method. Methods 200I, 25:402-408.

II. Mocellin S, Rossi CR, Pilati P, Nitti D, Marincola FM: Quantitative real-time PCR: a powerful ally in cancer research. Trends Mol Med 2003, 9: I 89-195.

12. Sturzenbaum SR, Kille P: Control genes in quantitative molecular biological techniques: the variability of invariance. Comp Biochem Physiol B Biochem Mol Biol 200I, 130:28I-289.

13. Ahmed FE, Vos PW, Holbert D: Modeling survival in colon cancer: a methodological review. Mol Cancer 2007, 6:15.

14. Altieri DC: Molecular circuits of apoptosis regulation and cell division control: the survivin paradigm. J Cell Biochem 2004, 92:656-663.

15. Yamamoto $\mathrm{H}, \mathrm{Ngan} \mathrm{CY}$, Monden M: Cancer cells survive with survivin. Cancer Sci 2008, 99:1709-1714.

16. Altieri DC: Survivin, cancer networks and pathway-directed drug discovery. Nat Rev Cancer 2008, 8:6I-70.

17. Wang TT, Qian XP, Liu BR: Survivin: potential role in diagnosis, prognosis and targeted therapy of gastric cancer. World J Gastroenterol 2007, 1 3:2784-2790.

18. Shen $\mathrm{C}, \mathrm{Hu} \mathrm{L}, \mathrm{Xia} \mathrm{L}, \mathrm{Li}$ Y: The detection of circulating tumor cells of breast cancer patients by using multimarker (Survivin, hTERT and hMAM) quantitative real-time PCR. Clin Biochem 2009, 42:194-200.

19. Yie SM, Lou B, Ye SR, He X, Cao M, Xie K, Ye NY, Lin R, Wu SM, Xiao HB, Gao E: Clinical significance of detecting survivinexpressing circulating cancer cells in patients with non-small cell lung cancer. Lung Cancer 2009, 63:284-290.

20. Yie SM, Lou B, Ye SR, Cao M, He X, Li P, Hu K, Rao L, Wu SM, Xiao $\mathrm{HB}, \mathrm{Gao} E$ : Detection of survivin-expressing circulating cancer cells (CCCs) in peripheral blood of patients with gastric and colorectal cancer reveals high risks of relapse. Ann Surg Oncol 2008, 15:3073-3082.

21. Psaila $B$, Lyden $D$ : The metastatic niche: adapting the foreign soil. Nat Rev Cancer 2009, 9:285-293.

22. Hiraiwa K, Takeuchi H, Hasegawa H, Saikawa Y, Suda K, Ando T, Kumagai K, Irino T, Yoshikawa T, Matsuda S, et al.: Clinical significance of circulating tumor cells in blood from patients with gastrointestinal cancers. Ann Surg Oncol 2008, I5:3092-3 I 00.

23. Illert B, Fein M, Otto C, Cording F, Stehle D, Thiede A, Timmermann W: Disseminated tumor cells in the blood of patients with gastric cancer are an independent predictive marker of poor prognosis. Scand J Gastroenterol 2005, 40:843-849.

24. Yeh KH, Chen YC, Yeh SH, Chen CP, Lin JT, Cheng AL: Detection of circulating cancer cells by nested reverse transcriptionpolymerase chain reaction of cytokeratin- 19 (K I9)--possible clinical significance in advanced gastric cancer. Anticancer Res 1998, 18:1283-1286.

25. Seo JH, Choi CW, Kim BS, Shin SW, Kim YH, Kim JS, Lee SW, Choi JH, Park YT, Mok Y], Kim CS: Follow-up study of peripheral blood carcinoembryonic antigen mRNA using reverse transcription-polymerase chain reaction as an early marker of clinical recurrence in patients with curatively resected gastric cancer. Am J Clin Oncol 2005, 28:24-29.

26. Wu CH, Lin SR, Hsieh JS, Chen FM, Lu CY, Yu FJ, Cheng TL, Huang TJ, Huang SY, Wang JY: Molecular detection of disseminated tumor cells in the peripheral blood of patients with gastric cancer: evaluation of their prognostic significance. Dis Markers 2006, 22:103-109.

27. Uen YH, Lin SR, Wu CH, Hsieh JS, Lu CY, Yu FJ, Huang TJ, Wang JY: Clinical significance of MUCI and c-Met RT-PCR detection of circulating tumor cells in patients with gastric carcinoma. Clin Chim Acta 2006, 367:55-6I.

28. Mimori K, Fukagawa T, Kosaka Y, Ishikawa K, Iwatsuki M, Yokobori T, Hirasaki S, Takatsuno Y, Sakashita $\mathrm{H}$, Ishii $\mathrm{H}$, et al.: A large-scale study of MTI-MMP as a marker for isolated tumor cells in peripheral blood and bone marrow in gastric cancer cases. Ann Surg Oncol 2008, I 5:2934-2942.

29. Pituch-Noworolska A, Kolodziejczyk P, Kulig J, Drabik G, Szczepanik A, Czupryna A, Popiela T, Zembala M: Circulating tumour cells and survival of patients with gastric cancer. Anticancer Res 2007, 27:635-640.

30. Ambrosini G, Adida C, Altieri DC: A novel anti-apoptosis gene, survivin, expressed in cancer and lymphoma. Nat Med 1997, 3:917-921.

31. Baran J, Pituch-Noworolska A, Krzeszowiak A, Wieckiewicz J, Stachura J, Pryjma J, Popiela T, Szczepanik A, Zembala M: Detection of cancer cells in the blood by FACS sorting of CD45- cells. Int J Mol Med 1998, 1:573-578.

\section{Publish with Bio Med Central and every scientist can read your work free of charge}

"BioMed Central will be the most significant development for disseminating the results of biomedical research in our lifetime. "

Sir Paul Nurse, Cancer Research UK

Your research papers will be:

- available free of charge to the entire biomedical community

- peer reviewed and published immediately upon acceptance

- cited in PubMed and archived on PubMed Central

- yours - you keep the copyright 